\title{
Nano Vanadyl-phthalocyanine Crystals Fabricated on KBr Substrate
}

\author{
Suguru Mototani Student Member \\ Shizuyasu Ochiai Member \\ Yoshiyuki Uchida Member \\ Asao Ohashi Member \\ Kenzo Kojima Member \\ Teruyoshi Mizutani Member
}

Keywords : Epitaxy, Vanadyl-phtalocyanine (VOPc), Nano crystal, Morphology, Molecular orientation, Molecular beam epitaxy method

\section{Introduction}

Devices using organic semiconductors and nonlinear optical materials have potential applications such as flexible displays, identification tags, electronic paper, large-area sensors, optical switches and optical IC. Many papers have been published on organic thin films of organic semiconductors and non-linear optics materials. Vanadyl-phthalocyanine (VOPc) film deposited on $\mathrm{KBr}$ (100) substrate shows a unidirectional molecular orientation with a square commensurate lattice and it has large nonlinear optical susceptibility. On the other hand, vanadylphthalocyanine, an organic semiconductor, is applicable as an active layer of the organic field effect transistor (OFET). However, the electrical/optical properties and optimum preparatory conditions of nano-VOPc crystals are not well understood. We investigated the relationship between the preparatory conditions and the morphology of nano-VOPc crystal formable on $\mathrm{KBr}$ substrate and obtained oriented nano-VOPc crystals, which were improved through annealing. Such nano-crystals are expected to be applied in organic electronic/optical devices.

\section{Experiments}

Nano-VOPc crystals were prepared on $\mathrm{KBr}(100)$ substrate using molecular beam epitaxy (MBE) equipment. The surface morphology of nano-VOPc fabricated on $\mathrm{KBr}$ substrate was observed by AFM. The morphology and orientation of nano-VOPc crystals were identified with Vis/UV spectra and X-ray diffraction.

\section{Results and Discussion}

Figure 1 shows an AFM image of the surface of the VOPc thin film with an evaporation time of $7 \mathrm{~min}$. and annealing at $150{ }^{\circ} \mathrm{C}$ for $180 \mathrm{~min}$. Many square-shaped nano-VOPc crystals can be seen in the AFM image of Figure 1. The AFM image of the sample before annealing shows many grains form a size smaller than that before annealing and the surface of grains lack the smoothness. In addition, their grains have molecular clusters. After annealing, the size of nano-crystals is larger than that before annealing and the number of small nano-crystals markedly decreases with the annealing. Furthermore, the surface of the nano-crystals is smother than that before annealing, which indicates that during annealing, small grains merge with one another through thermal diffusion and many clusters existing around the grain adhere to the grain by thermal annealing.

In annealing treatment at $150{ }^{\circ} \mathrm{C}$ for $360 \mathrm{~min}$, the grain size grew larger than that after the thermal annealing at $150{ }^{\circ} \mathrm{C}$ for 180 min., and the contact between grains caused distortion inside the grain. In the sample prepared with an evaporation time of $15 \mathrm{~min}$., grains having a unidirectional orientation can be seen in the AFM image. This indicates that during the evaporation time, VOPc molecules adhering on $\mathrm{KBr}(100)$ substrate move to epitaxial sites on the substrate and then, form a commensurate square lattice of $3 \times 3 \mathrm{R} 45^{\circ}$. After that, VOPc molecules arriving on the substrate are deposited with epitaxial growth. This also means that grains formed with the evaporation time of $15 \mathrm{~min}$. on the substrate are in a unidirectional orientation. Annealed at $150{ }^{\circ} \mathrm{C}$ for $180 \mathrm{~min}$., the grain is a size larger and adheres in clusters more than before annealing. In addition, the grains form in a unidirectional orientation. These findings indicate that the formation of clusters with the thermal diffusion of VOPc molecules adhering on the substrate and the cluster and grain are absorbed and merged, moreover, grains on the substrate are absorbed and merged. Also, the evaporation and annealing time are closely related to the unidirectional orientation of grains on the substrate. In annealing treatment at $150{ }^{\circ} \mathrm{C}$ for $360 \mathrm{~min}$., the contact between grins occur the distortion inside the grain.

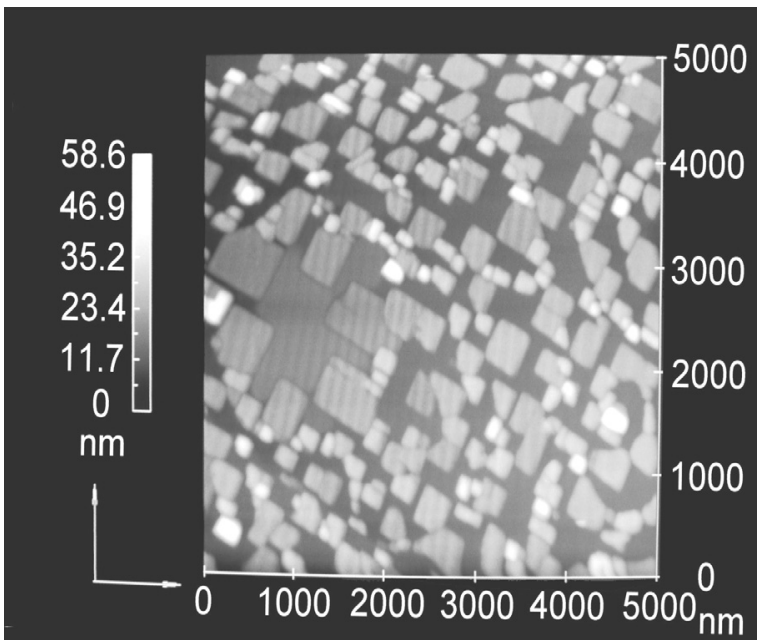

Fig. 1. AFM image of the surface of the VOPc thin film after the thermal annealing at $150{ }^{\circ} \mathrm{C}$ for $180 \mathrm{~min}$ 


\title{
臭化カリウム基板上に作成されたバナジルフタロシアニンナノ結晶
}

$\begin{array}{cccccc}\text { 学生員 元谷 } & \text { 卓* } & \text { 正 員 落合 } & \text { 鎮康* } \\ \text { 正員 内田 } & \text { 悦行* } & \text { 正 員 大橋 } & \text { 朝夫* } \\ \text { 正員 小嶋 } & \text { 憲三* } & \text { 正員 水谷 } & \text { 照吉* }\end{array}$

\author{
Nano Vanadyl-phthalocyanine Crystals Fabricated on KBr Substrate \\ Suguru Mototani*, Student Member, Shizuyasu Ochiai*, Member, Yoshiyuki Uchida*, Member, Asao Ohashi*, Member, \\ Kenzo Kojima*, Member, Teruyoshi Mizutani*, Member
}

\begin{abstract}
Vanadyl-phthalocyanine (VOPc) thin film deposited on a $\mathrm{KBr}$ substrate by the molecular beam epitaxy (MBE) method consists of nano-VOPc crystals grown with epitaxy. The nano-VOPc crystal becomes a commensurate square shape by the annealing treatment at $150^{\circ} \mathrm{C}$. Moreover, the size of the nano-crystal is controllable by changing the conditions of the MBE deposition and the thermal treatment. The growth processes of nano-crystals on $\mathrm{KBr}$ substrate are clarified experimentally and they are closely related to a strong interaction between VOPc molecule and $\mathrm{KBr}$ substrate. Their mechanisms can be explained in terms of the surface diffusion of the VOPc moleculs on $\mathrm{KBr}$ substrate.
\end{abstract}

キーワード : エピタキシ, バナジルフタロシアニン $(\mathrm{VOP})$, 結晶形態, 分子配向, ナノ結晶, 分子線エピタキシ(MBE)法

Keywords : epitaxy, vanadyl-phtalocyanine (VOPc), morphology, molecular orientation, nano crystal, molecular beam epitaxy method

\section{1. はじめに}

無機半導体であるシリコンをベースとするマイクロエレ クトロニクス集積化技術の微細加工に限界が見え始めてい ることから，有機材料の持つ特徴を十分に活用した有機電 子・光デバイスの開発が脚光を浴びている。そのため, 非 線形光学特性や電気特性を自由に制御できる有機機能材料 の作成技術およびその素子化技術の確立が重要である(1)。

近年，無機材料に比し大きな非線形光学感受率を示す有 機非線形光学材料が注目されている。例えば, $\operatorname{KBr}(100)$ 基板 面上に堆積されたバナジルフタロシアニン(VOPc)薄膜が一 軸配向し, エピタキシャル成長すること ${ }^{(3)(6),(7)}$, 大きな非 線形光学感受率 $\chi^{(3)}$ を持つことが知られてい る (2)(4)。他方, VOPc は半導体の性質を有することから, 有 機電界効果トランジスタの活性層への採用も検討されてい る。これらのことから, 今後, VOPc 薄膜は有機電子・光デ バイス用材料として重要な役割を果たすものと考えられて いる。

本研究では，有機ナノ電子・光デバイスの作成を目指し， 良質なナノ VOPc 結晶の作成条件とその機構について検討 した。KB r 基板上にナノ VOPc 結晶 $\left(100 \times 100 \mathrm{~nm}^{2}\right.$ 程度)が得

\footnotetext{
* 愛知工業大学

T470-0392＼cjkstart愛知県豊田市八草町八千草 1247

Aichi Inst. of Tech., Yakusa-cho, Toyota 470-0392, JAPAN
}

られることを見いだし, その成長過程や熱処理効果の詳細 を実験的に明らかにし，その成長機構について考察した。 この有機ナノVOPc 結晶がナノサイズ電界効果トランジス タ, IC, 光論理素子, 光スイッチング素子, 光メモリ, 光 IC の作成に適用すること可能であることから, 有機ナノテ クノロジーの大きな進展が期待される。

\section{2. 実験方法}

分子線エピタキシ(MBE)装置（島津製作所製 SLC-29 型） により, 真空度 $10^{-7} \mathrm{~Pa}$ 台で, バナジルフタロシアニン (VOPc) を臭化カリウム $(\mathrm{KBr})$ 基板上に堆積させた。図 1 に VOPc の 分子構造を示す。VOPc 分子はピラミッド 5 配位構造を有し, 分子の長径が $1.4 \mathrm{~nm}$, 高さが $0.2 \mathrm{~nm}$ である。大気中で VOPc を $0.1 \mathrm{~g}$ 計量し, 蒸着前に真空中で $300^{\circ} \mathrm{C}, 120 \mathrm{~min}$. 予備加熱 した。次に, 蒸着前に大気中で $10 \times 10 \times 0.5 \mathrm{~mm}^{3}$ に䢃開した $\mathrm{KBr}$ 基板を真空中 $300{ }^{\circ} \mathrm{C}, 60 \mathrm{~min}$. 予備加熱した。VOPc 薄 膜の蒸着後, 真空中で熱処理を施した。各試料の蒸着条件
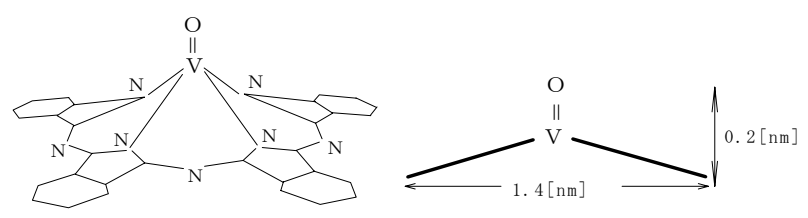

図 $1 \operatorname{VOPc}$ の分子構造

Fig. 1. Molecular structure of VOPc molecule. 
Table 1. Preparatory conditions of VOPc thin films on $\mathrm{KBr}$ substrate with an evaporation time of 5 minutes and no annealing in Sample 1, annealing for 180 minutes in Sample 2 and annealing for 360 minutes in Sample 3.

\begin{tabular}{|c|c|c|c|}
\hline Sample No. & 1 & 2 & 3 \\
\hline Substrate & \multicolumn{3}{|c|}{$\operatorname{KBr}(100)$} \\
\hline Vacuum $(\mathrm{Pa})$ & \multicolumn{3}{|c|}{$10^{-7}$} \\
\hline Evaporating temp. $\left({ }^{\circ} \mathrm{C}\right)$ & \multicolumn{3}{|c|}{300} \\
\hline Evaporating time (min.) & \multicolumn{3}{|c|}{7} \\
\hline $\begin{array}{l}\text { Preheating temp. of } \\
\text { substrate }\left({ }^{\circ} \mathrm{C}\right)\end{array}$ & \multicolumn{3}{|c|}{300} \\
\hline Substrate temp. $\left({ }^{\circ} \mathrm{C}\right)$ & \multicolumn{3}{|c|}{150} \\
\hline Annealing time (min.) & 0 & 180 & 360 \\
\hline Annealing temp. $\left({ }^{\circ} \mathrm{C}\right)$ & \multicolumn{3}{|c|}{150} \\
\hline Thickness (nm) & 9 & 13 & 12 \\
\hline
\end{tabular}

Table 2. Preparatory conditions of VOPc thin film on $\mathrm{KBr}$ substrate with an evaporation time of 15 minutes and no annealing in Sample 1, annealing for 180 minutes in Sample 2 and annealing for 360 minutes in Sample 3.

\begin{tabular}{|l|c|c|c|}
\hline Sample No. & 4 & 5 & 6 \\
\hline Substrate & \multicolumn{3}{|c|}{$\mathrm{KBr}(100)$} \\
\hline Vacuum (Pa) & \multicolumn{3}{|c|}{300} \\
\hline Evaporating temp. ( $\left.{ }^{\circ} \mathrm{C}\right)$ & \multicolumn{3}{|c|}{15} \\
\hline Evaporating time (min. $)$ & \multicolumn{3}{|c|}{300} \\
\hline $\begin{array}{l}\text { Preheating temp. of } \\
\left.\text { substrate ( }{ }^{\circ} \mathrm{C}\right)\end{array}$ & \multicolumn{3}{|c|}{150} \\
\hline Substrate temp. ( $\left.{ }^{\circ} \mathrm{C}\right)$ & 0 & 180 & 360 \\
\hline Annealing time (min. $)$ & 15 & 20 & 24 \\
\hline Annealing temp. ( $\left.{ }^{\circ} \mathrm{C}\right)$ & \multicolumn{3}{|c|}{} \\
\hline Thickness (nm) & \multicolumn{3}{|c|}{} \\
\hline
\end{tabular}

及び膜厚を表 1，2 に示す。作成した VOPc 薄膜の表面形態 を原子間力顕微鏡(AFM) (OLYMPUS 製 NV2000 型)により 評価した。バルクの形態評価を可視・紫外 $(\mathrm{Vis} / \mathrm{UV})$ 分光 光度計（島津製作所製 UV-2450 型），基板上の VOPc 分子の 配向, 配列評価を X 線回折装置(XRD 島津製作所製 XD-D1) により行った。

\section{3. 実験結果及び検討}

〈3・1〉Vis/UVスペクトル 図 2 に試料 1〜3 の吸収ス ペクトルを示す。各試料とも $780 \mathrm{~nm}$ 付近の吸収ピークと $810 \mathrm{~nm}$ 付近にショルダーが見られる。このことは擬似エピ タキシとエピタキシで堆積された膜であることを示唆す る(5)。180min の熱処理を施した試料 2 では, $780 \mathrm{~nm}$ に吸収 のピークを持つ擬似エピタキシ成分に比し，810nm にショ ルダーを有するエピタキシ成分が増大することが分かる。 これは, VOPc 膜の擬似エピタキシ層の歪みが緩和され, エ ピタキシ層へ転移することを示唆する。一方，熱処理を $360 \mathrm{~min}$ 施した試料 3 では $780 \mathrm{~nm}$ の吸収ピークが増大し, $810 \mathrm{~nm}$ のショルダーが小さくなる。このことは, 熱処理に

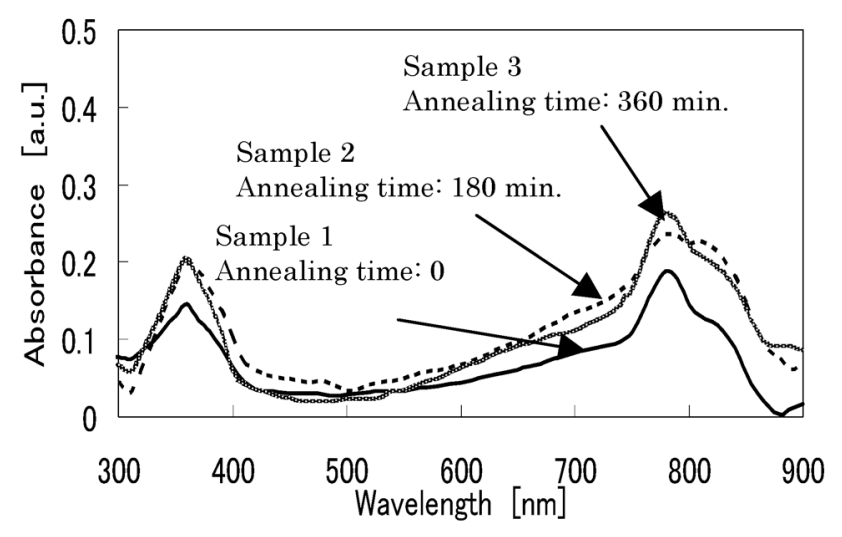

図 $2 \mathrm{KBr}$ 基板上に作成された試料 1〜3の Vis/UV スペクトル

Fig. 2. Vis/UV spectra of Samples 1 to 3 prepared on $\mathrm{KBr}$ substrate.

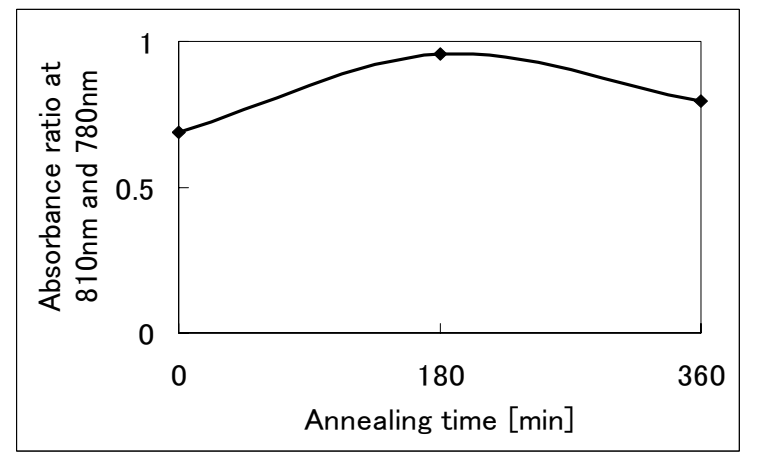

図 3 熱処理時間に対する $810 \mathrm{~nm}$ と $780 \mathrm{~nm}$ の吸光度比

Fig. 3. Absorbance ratio at 810 and $780 \mathrm{~nm}$ vs. annealing time.

より膜内部の歪みが増大した可能性を示唆する。これらの 根拠は設楽等により報告された歪の除去が擬似エピタキシ ヤル成長からエピタキシャル成長の転移に関係することに 依拠している ${ }^{(8)}$ 。

図 3 に $780 \mathrm{~nm}$ と $810 \mathrm{~nm}$ の吸光度比の熱処理時間依存性を 示す。熱処理により膜歪みが一旦緩和されるが，さらなる 熱処理により，歪みが増大することが分かる。

図 4 に試料 $4 \sim 6$ の $\mathrm{KBr}$ 基板上に堆積された VOPc 薄膜の 吸収スペクトルを示す。各試料とも図 2 と同様なスペクト ルパターンを示すことから, 図 2 の試料と同様な堆積膜で あることが理解される(5)。また, 熱処理時間の増加と共に擬 似エピタキシが増大寸ることが分かる。これは熱処理によ り膜内部の歪みが増大した可能性が考えられる ${ }^{(8)}$ 。

図 5 は, $780 \mathrm{~nm}$ と $810 \mathrm{~nm}$ の吸光度比がアニール時間の増 大により低下することを示している。これは試料 1〜3に比 し, VOPc 堆積時間が長いこと, 言い換えれば, 膜厚が厚い ことに関係する。

〈3·2〉 XRD プロフィール 図 6 に試料 $1 \sim 6$ の XRD プロフィールを示す。試料 $1 \sim 6$ では, 回折ピークが $2 \theta$ : 


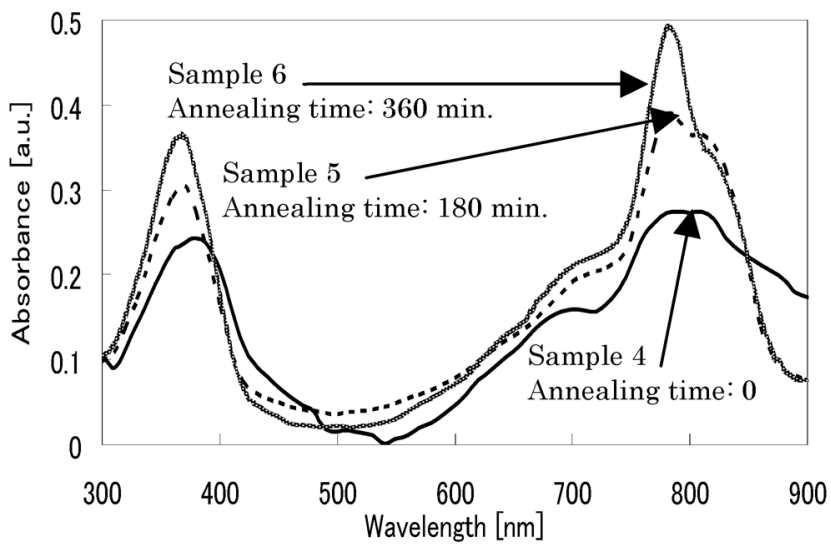

図 $4 \mathrm{KBr}$ 基板上に作成された試料 4〜6 の Vis/UV スペクトル

Fig. 4. Vis/UV spectra of Samples 4 to 6 prepared on $\mathrm{KBr}$ substrate.

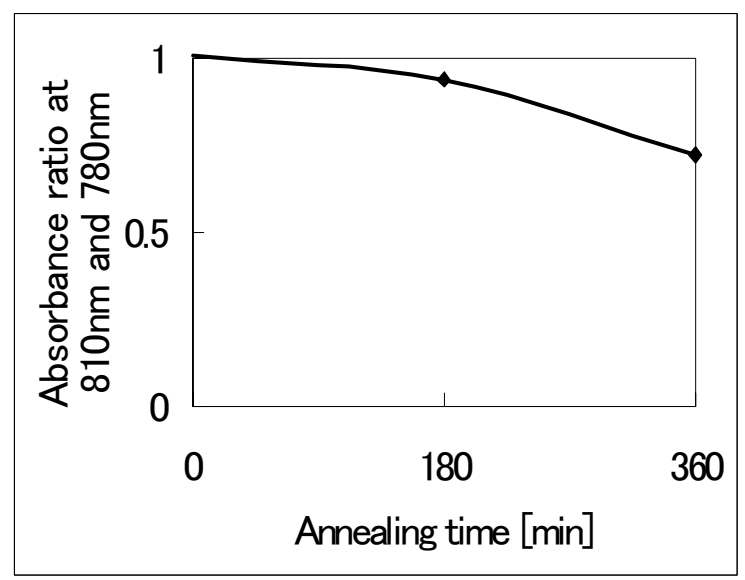

図 5 熱処理時間に対する $810 \mathrm{~nm}$ と $780 \mathrm{~nm}$ の吸光 度比

Fig. 5. Absorbance ratio at 810 and $780 \mathrm{~nm}$ vs. annealing time.

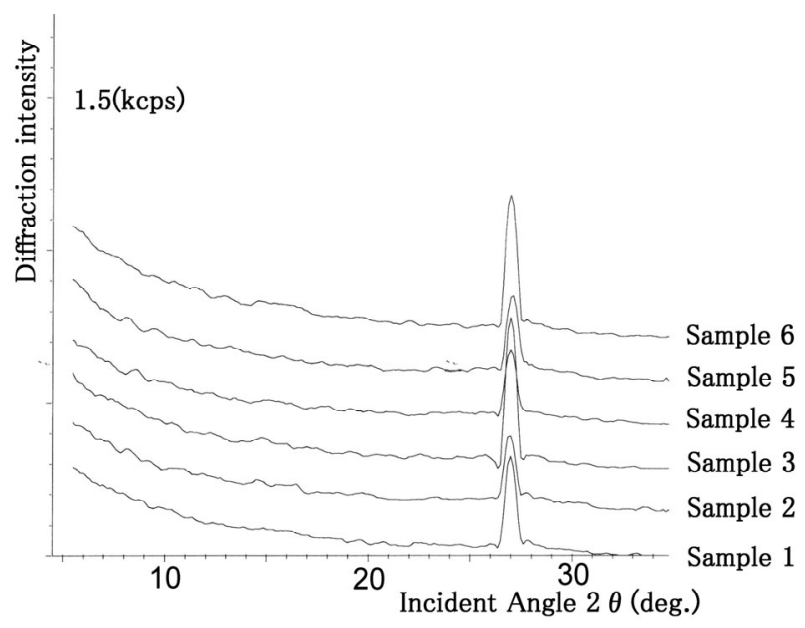

図 $6 \mathrm{KBr}$ 基板上に作成された試料 $1 \sim 6$ の XRD

$$
\text { プロフィール }
$$

Fig. 6. XRD profiles of Samples 1 to 6 prepared on $\mathrm{KBr}$ substrate. $27.0^{\circ}$ （面閒隔 $0.33 \mathrm{~nm}$ ）に存在することから, VOPc 分子が $\mathrm{KBr}$ 基板上に平行配向していることが示唆される。

〈3.3〉 AFM 観察 有機分子線蒸着に基づく, 基板上 の島状結晶成長モデルが次のように, 提案されている。蒸 着源から飛来した蒸着分子が基板表面に一部吸着し, 吸着 分子の表面拡散に伴い次第に結晶核が形成され，結晶核の 成長により，グレインが成長する。その後，グレイン間の 吸収, 合併により, 島状結晶（ナノ結晶）が成長する。そ れに続き, 島状結晶へのグレインの吸収, 合併, 飛来分子 の拡散, 吸着に基づき, 大形結晶が成長する(9)。これを基に, 図 7-10 の AFM 像を検討する。図 7 に試料 1 の AFM 像を 示す。試料 1 では, 蒸着時間が $7 \mathrm{~min}$. と短く, 基板上の飛来 分子が少なく, 十分な表面拡散が行われていないため, 多 くのグレイン或いは凝集体が確認される。また, 僅かな配 向性を持ちながら, $\mathrm{KBr}$ 基板表面にグレインが成長してい ることが分かる。

図 8 に試料 2 の AFM 像を示す。1 80 min.の熱処理を施す ことにより, 離散的にナノ結晶が観察される。蒸着時間が 短い為にナノ結晶が小さく，また数が少ないことが分かる。 さらに，ナノ結晶の大きさにバラつきがあることが分かる。 しかし, ナノ結晶上に残留するグレイン或いは凝集体の数 が少なく平滑なナノ結晶が観察される。これは, グレイン 間の吸収, 合併と VOPc 分子の表面拡散に原因する。

図 9 に図 8 の拡大図を示す。図 8 の AFM 像を拡大寸ると 離散的にナノ結晶が存在すること, 配向の若干の乱れが明 確に観察される。作成されたナノ結晶のサイズにバラつき があるが，最大 $500 \mathrm{~nm} \times 500 \mathrm{~nm}$ ナノ結晶が見られ，表面が 平滑であることが分かる。

図 10 に試料 3 の AFM 像を示す。360 min.の熱処理により

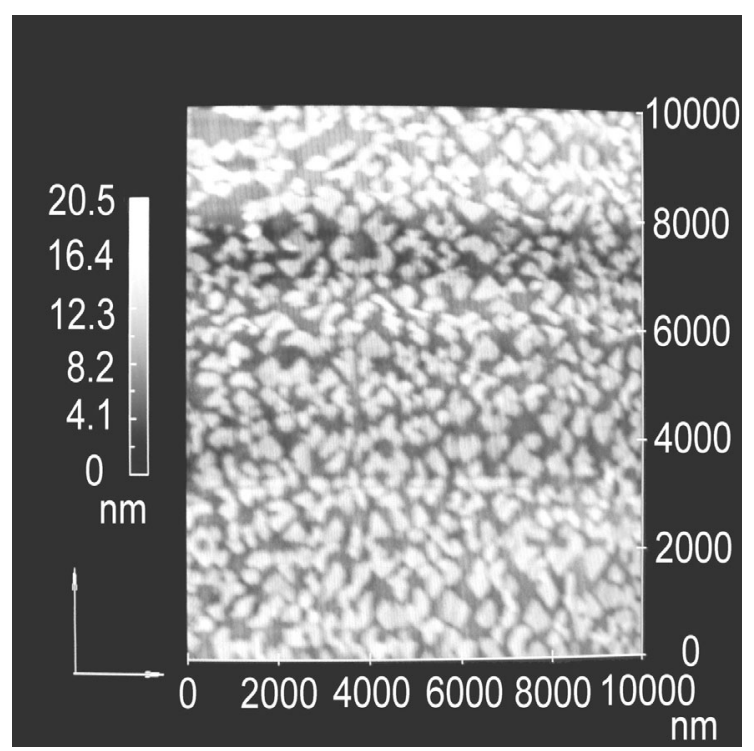

図 7 as deposited 試料 1 の AFM 像倍率 $1000 \times 1000 \mathrm{~nm}^{2}$

Fig. 7. AFM image of Sample 1 as deposited.

Magnification: $10000 \mathrm{~nm} \times 10000 \mathrm{~nm}^{2}$ 


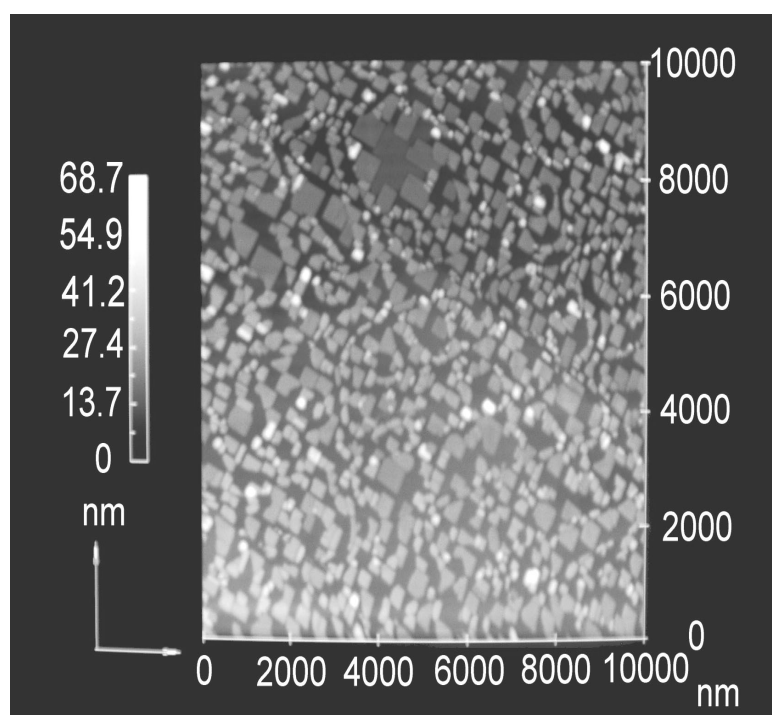

図 8180 分間熱処理した試料 2 の AFM 像倍率 $1000 \times 1000 \mathrm{~nm}^{2}$

Fig. 8. AFM image of Sample 2 annealed for 180 minutes. Magnification: $10000 \times 10000 \mathrm{~nm}^{2}$

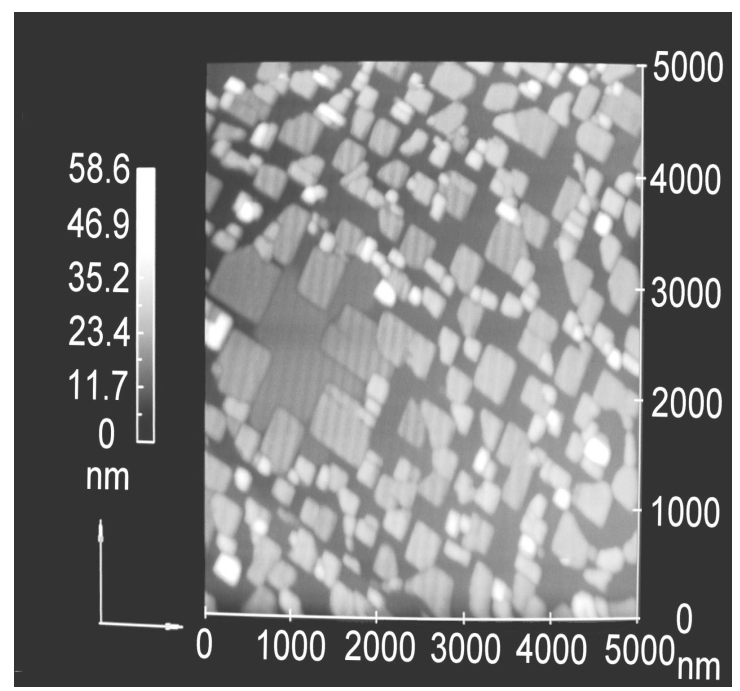

図 9180 分間熱処理した試料 2 の AFM 像倍率 $5000 \times 5000 \mathrm{~nm}^{2}$

Fig. 9. AFM image of Sample 2 annealed for 180 minutes.

Magnification: $5000 \times 5000 \mathrm{~nm}$

表面の平滑なナノ結晶が高密度に形成されることが分か る。試料 3 は試料 2 の倍の熱処理時間のため, 試料 2 に比 し, ナノ結晶の発生が高密度化することが分かる。そのた め, 所々で結晶間が接触し, 結晶内部の歪みの原因になる。 これは熱処理中のグレインの吸収，合併と密接に関係する。 また，十ノ結晶の長方形状の各辺が丸みを帯びていること が分かる。これは, ナノ結晶を形成する分子の脱離に関係 することが示唆される。図 11 に試料 4 の AFM 像を示す。 試料 1 に比べ, 蒸着時間を 2 倍長くすることで, 試料 1 で は見られなかった島状結晶が観察される。また，グレイン が一軸配向していることが分かる。図 11 では, 図 7 に比し,

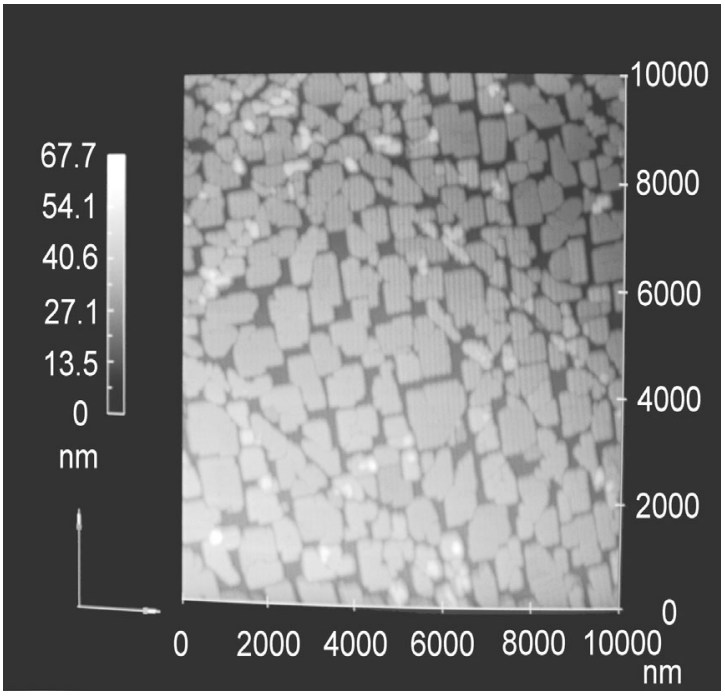

図 10360 分間熱処理した試料 3 の AFM 像倍率 $10000 \times 10000 \mathrm{~nm}^{2}$

Fig. 10. AFM image of Sample 3 annealed for 360 minutes. Magnification: $10000 \times 10000 \mathrm{~nm}^{2}$

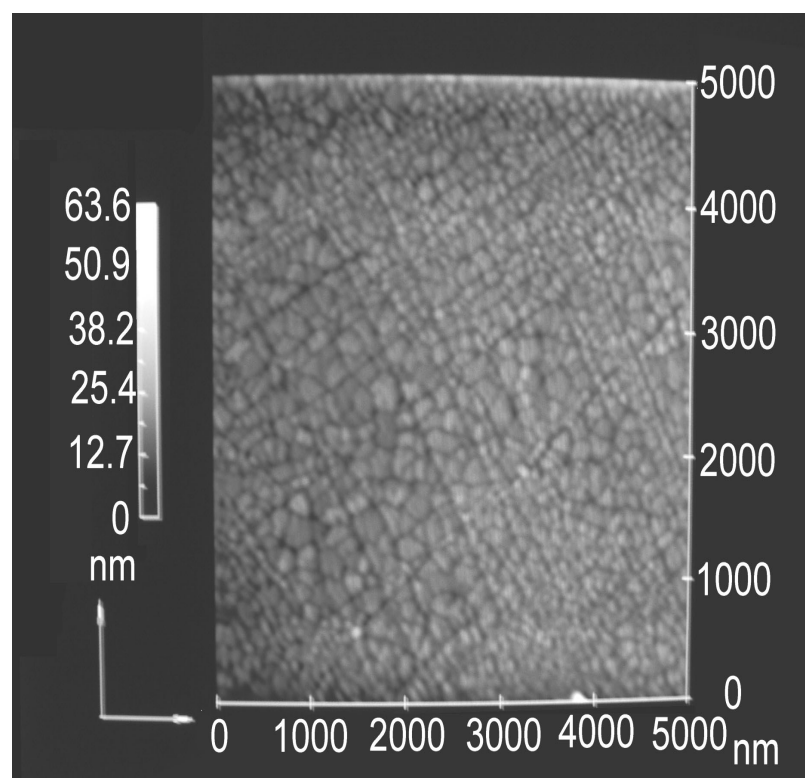

図 11 as deposited 試料 4 の AFM 像倍率 $5000 \times 5000 \mathrm{~nm}^{2}$

Fig. 11. AFM image of Sample 4 as deposited.

Magnification: $5000 \mathrm{~nm} \times 5000 \mathrm{~nm}^{2}$

蒸着時間が 2 倍であるため, 基板と VOPc 分子の相互作用の 大きいエピタキシアルサイトに飛来の VOPc 分子が配向, 配 列し，島状結晶が成長し，エピタキシアル成長すること， そして $\mathrm{KBr}$ 基板上で一軸配向することが考えられる。

図 12 に試料 5 の AFM 像を示す。ナノ結晶が形成される 中間状態が観察される。1 $80 \mathrm{~min}$.の熱処理により, 一軸配向 を持つナノ結晶が多数観察される。試料 2 では, ナノ結晶 が離散的に形成され, サイズにバラつきが見られたが, 試 料 5 では, $\mathrm{KBr}$ 基板表面に全体的に均一なナノ結晶の形成 


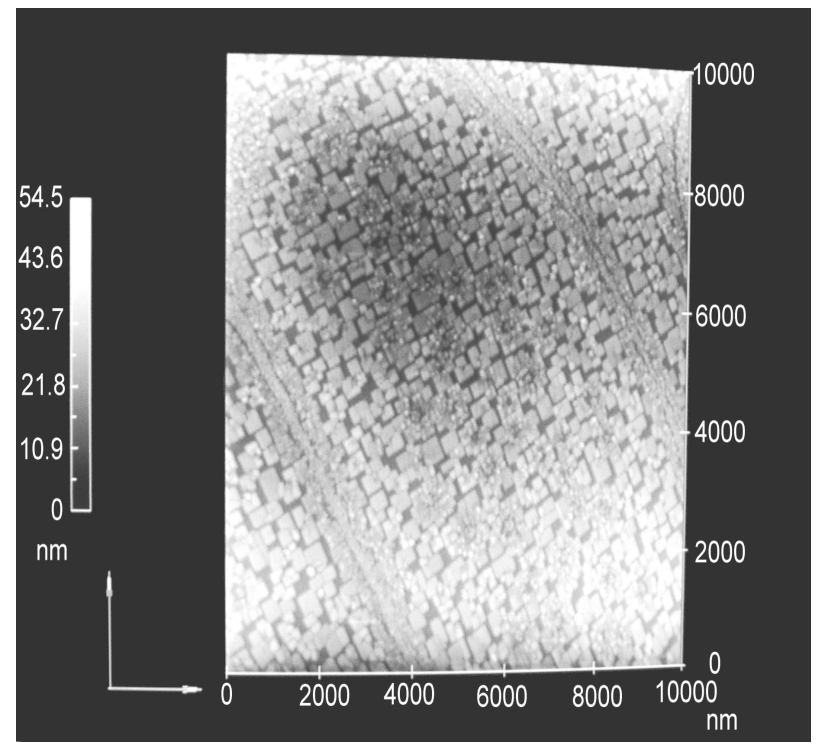

図 12180 分間熱処理した試料 5 の AFM 像倍率 $10000 \times 10000 \mathrm{~nm}^{2}$

Fig. 12. AFM image of Sample 5 annealed for 180 minutes.

Magnification: $10000 \times 10000 \mathrm{~nm}^{2}$

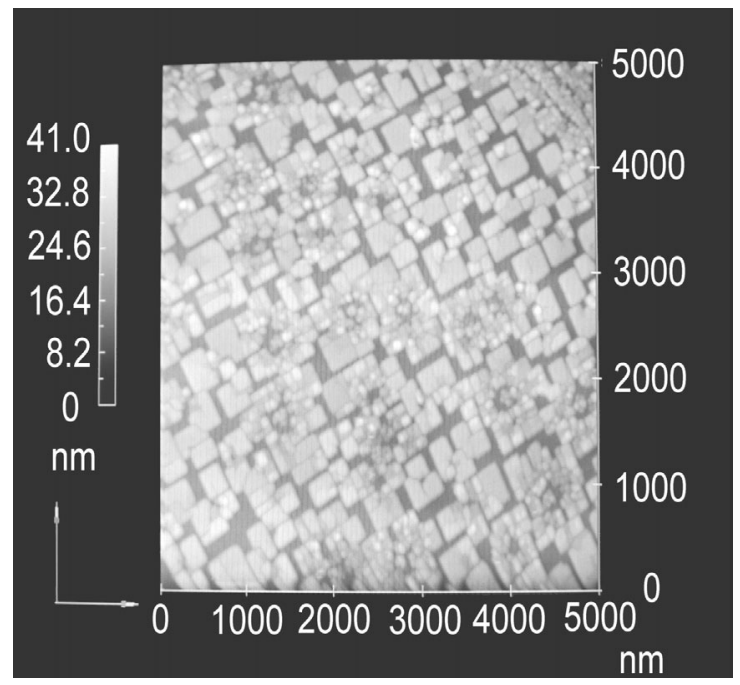

図 13180 分間熱処理した試料 5 の AFM 像倍率 $5000 \times 5000 \mathrm{~nm}^{2}$

Fig. 13. AFM image of Sample 5 annealed for 180 minutes.

Magnification: $5000 \times 5000 \mathrm{~nm}^{2}$

が確認される。アニールに伴い, 島状結晶サイズが大きく なる。これは, アニールにより, グレインが吸収, 合併を 繰返し，島状結晶サイズが増大寸ることを示唆する。

図 13 に図 12 の拡大 AFM 像を示す。図より, 熱処理によ り $\mathrm{KBr}$ 基板上の VOPc 分子及び分子凝集体（クラスター） が表面拡散, 凝集再結晶し, ナノ結晶が成長することが分 かる。また, ナノ結晶が一軸配向し, 正方形状結晶を形成 することから， $\mathrm{KBr}(100)$ 基板上に $3 \times 3 \mathrm{R} 45^{\circ}$ の正方格子で堆 積していることが分かる

図 14 に試料 6 の $\mathrm{AFM}$ 像を示す。360 min.の熱処理により,

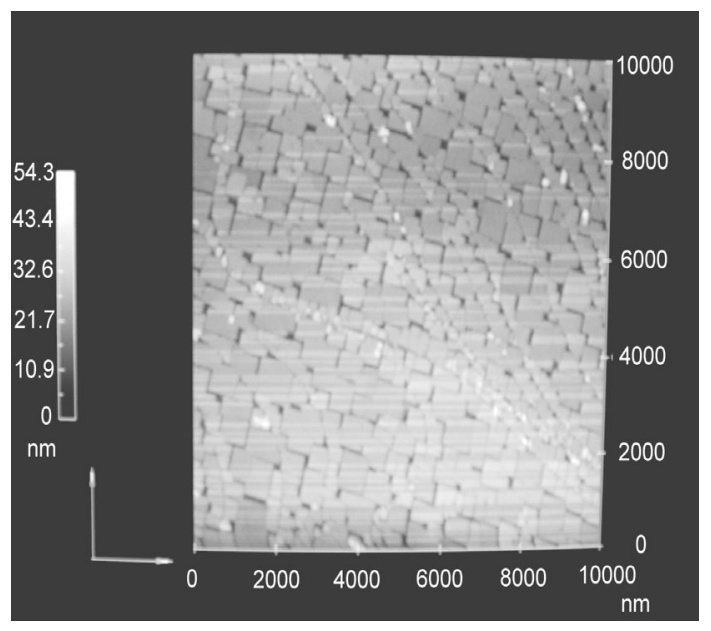

図 14360 分間熱処理した試料 6 の AFM 像倍率 $10000 \times 10000 \mathrm{~nm}^{2}$

Fig. 14. AFM image of Sample 6 annealed for 360 minutes. Magnification: $10000 \times 10000 \mathrm{~nm}^{2}$

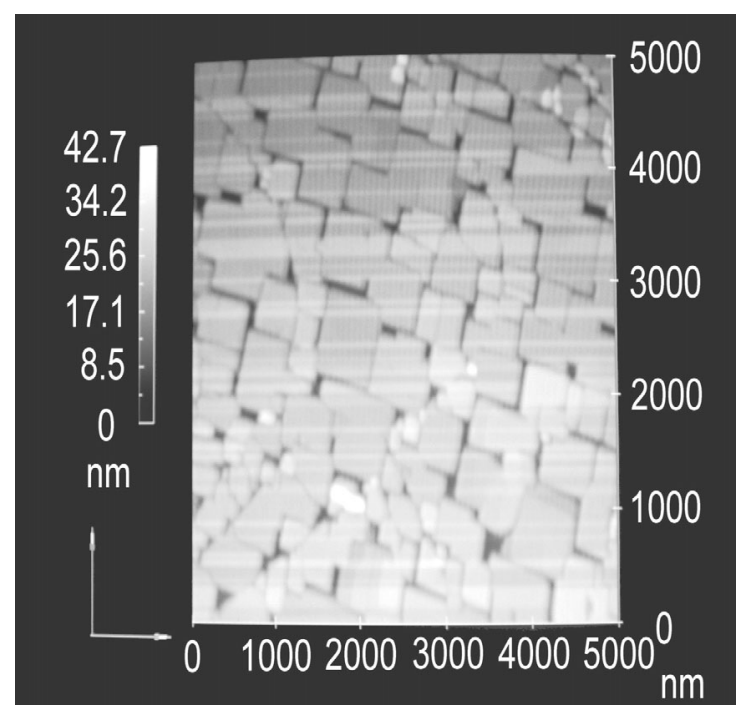

図 15360 分間熱処理した試料 6 の AFM 像倍率 $5000 \times 5000 \mathrm{~nm}^{2}$

Fig. 15. AFM image of Sample 6 annealed for 360 minutes. Magnification: $5000 \times 5000 \mathrm{~nm}^{2}$

ナノ結晶が試料 5 より平滑かつ, 大形化し, 分子凝集体 (ク ラスター) が観察されない。これは熱処理によりVOPc 分子 の拡散, クラスター合併により, ナノ結晶が形成されるこ とを示唆する。図 15 に図 14 の拡大図を示す。ナノ結晶の 密度が高く, 結晶間が接触し, ナノ結晶中に歪みが発生す る原因になっていると考えられる。このため, 擬似エピタ キシ成分が熱処理時間と共に増大した可能性が高い。これ は，先の Vis/UV スペクトルの結果を支持する。

\section{4. まとめ}

本論文を要約すると，以下の通りである。

$\mathrm{KBr}$ 基板上に堆積された VOPc 超薄膜の AFM 像から, $\mathrm{KBr}$ 
基板上では, VOPc 分子と基板との強い相互作用により, エ ピタキシャル島状結晶（ナノ結晶）が成長する。アニール 処理により, ナノ結晶サイズが増大し, ナノ結晶が擬似か らエピタキシャル結晶に転移する。長時間アニールでは, ナノ結晶サイズの増大に伴い, ナノ結晶間が接触し, ナノ 結晶内部の歪の原因になる。

蒸着時間 $7 \mathrm{~min}$., 熱処理なしでは, VOPc 分子の表面拡散, グレインの吸収, 合併が不十分な為, $\mathrm{KBr}$ 基板上に均一な ナノ結晶が形成しない。熱処理では，ナノ結晶が成長する が飛来分子の量が少ないため, その密度が低いことが観測 される。また, 熱処理時間の増大により, グレインの吸収, 合併が促進され, ナノ結晶のサイズが増大し, 結晶間で接 触が発生するため, 結晶内部の歪の原因になる。

蒸着時間 $15 \mathrm{~min}$., 熱処理なしでは, 多数のナノ結晶が形 成し, 一軸配向する。これらは長時間蒸着に基づく, VOPc 分子のエピタキシアルサイトへの移動, 吸着し, 基板上に 正方平方格子 $\left(3 \times 3 \mathrm{R} 45^{\circ}\right)$ を形成し, エピタキシアル成長 することを示唆する。180min.熱処理では, 熱拡散, クラス ターのグレインへの吸収, グレインの吸収, 合併により, ナノ結晶サイズが大形, 均一化し, 一軸配向するが長時間 蒸着により, ナノ結晶付近に多数のクラスターが存在し, クラスターがナノ結晶の歪の原因である可能性が高い。 360min. 熱処理では, クラスターが消失し, ナノ結晶表面が 平滑化され, ナノ結晶サイズが増大するがナノ結晶間で接 触を生ずる。これらは長時間蒸着に基づく, VOPc 分子の熱 拡散, クラスターのグレインへの吸収, グレインの吸収, 合併に原因し, ナノ結晶間の接触が結晶内部の歪の原因に なることを示唆する。

\section{謝 辞}

本研究は, 文部科学省私学助成学術フロンティア事業「21 世紀を支えるための材料の開発一環境，エネルギー，情報 に資する材料開発のための基礎研究—」(平成 14一 18 年度) の研究の一環として行われたものである。

(平成 18 年 3 月 14 日受付, 平成 18 年 8 月 4 日再受付)

\section{文献}

(1) S. Mototani, S. Ochiai, S. Goro, Y. Uchida, A. Ohashi, K. Kojima, and T. Mizutani : "Growing Process of Vanadylphthalocyanine thin film deposited on Two Types of Substrate", J. Vac. Soc. Jpn, Vol.49, No.6, pp.46-48 (2006) (in Japanese) 元谷 卓・落合鎮康・澤 五郎 $\cdot$ 内田悦行 $\cdot$ 大橋朝夫 - 小嶋憲三 水谷照吉:「バナジルフタロシアニン薄膜の初期成長過程に及ぼす基 板の効果」, 真空, 49, 6, pp.46-48 (2006)

(2) Q. Jiang, G. Sawa, Y. Uchida, K. Kojima, A. Ohashi, S. Ochiai, and T. Mizutani : "Film Thickness Dependence of Nonlinear Optical Intensity and Morphology of Vanadyl-Phthalocyanine Thin Film Deposited on $\mathrm{KCl}$ (100) Subustrate", J. Vac. Soc. Jpn, Vol.46, No.3, pp.150-152 (2003) (in Japanese)

蒋 琴 ・澤 五郎 $\cdot$ 内田悦行 - 小嶋憲三 · 大橋朝夫 ・ 落合鎮康 - 水 谷照吉 :「塩化カリウム(100)基板上に作製されたバナジルフタロシ アニン薄膜の形態と非線形光学強度の膜厚依存性」, 真空, 43, 3, pp.150-152 (2003)
( 3 ) H. Hoshi and Y. Maruyama : "Epitaxial growth of choloroaluminum and vanadyl phthalocyanine film on alkali halide single crystals by the molecular-beam-epitaxy technique", J. Appl. Phys., Vol.69, No.5, pp.3046-3052 (1991)

(4) S. Fang, H. Tada, and S. Mashiko : "Enhancement of the third-order nonlinear optical susceptibility in epitaxial vanadyl-phthalocyanine films grows on KBr", Appl. Phys. Lett., Vol.69, No.6, pp.767-769 (1996)

( 5 ) H. Hoshi, K. Hamamoto, T. Yamada, K. Ishikawa, H. Takezoe, A. Fukuda, S. Fang, K. Kohama, and Y. Maruyama : "Thickness Dependence of the Epitaxial Structure of Vanadyl Phthalocyanine Film", Jpn. J. Appl. Phys., Vol.33, No.11A, pp.L1555-L1558 (1994)

(6) H. Yanagi, T. Mikami, H. Tada, T. Toshifumi, and S.Mashiko : "Molecular stacking in epitaxial crystal of oxometal phthalocyanines", J. Appl. Phys., Vol.81, No.11, pp.7306-7312 (1997)

( 7 ) H. Tada and S. Mashiko : "Computer Simulation for Molecular Orientation of Vanadyl Phthalocyanine in Epitaxal Form", Jpn. J. Appl. Phys., Vol.34, part 1, No.7B, pp.3889-3897 (1995)

(8) T. Shidara, Y. Jin, Y. Uchida, K. Kojima, A. Ohashi, S. Ochiai, and T. Mizutani : "Nonlinear Optical Properties and Organic Gas Effects of VOPc Thick Films Prepared on KBr Substrate", IEEJ Trans. EIS, Vol.123, No.10, pp.1706-1713 (2003-10) (in Japanese) 設楽俊孝・金 永龍 - 内田悦行 - 小嶋憲三 · 大橋朝夫, 落合鎮康 $\cdot$ 水谷照吉: 「 $\mathrm{KBr}$ 基板上に堆積されたバナジルフタロシアニン厚膜の 有機ガス処理効果と非線形光学特性」, 電学論 C, 123, 10, pp.1706-1713 (2003-10)

(9) K. Yase : "Ultra-thin Films Prepared by Organic Molecular Beam Deposition Techniques, Journal of the National Institute of Materials and Chemical Research", Vol.2, No.2, Chapter 2, p.243 (1994) (in Japanese) 八瀬清志 :「有機分子線蒸着等による超薄膜に関する調査研究」, 第 2 巻, 第 2 号, 2 章, p.243 (1994)

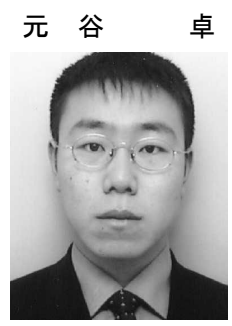

(学生員) 1982 年 3 月 11 日生。 2004 年 3 月愛 知工業大学卒業。現在, 愛知工業大学大学院工 学研究科電気電子工学専攻, 在学中。非線形光 学材料の作成とその応用に関する研究に従事。

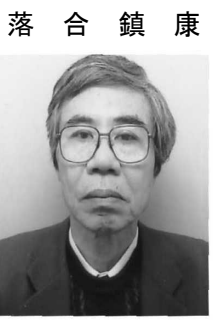

（正員） 1944 年 1 月 1 日生。1966 年 3 月愛知 工業大学電気工学科卒業。同年愛知工業大学電 気工学科助手。1990 年 10 月〜3 年 9 月まで米 国・クラークソン大学研究員。酸化物高温超電 導体の伝導機構の解明, 非線形光学材料の作成 とその応用に関寸る研究に従事。現在, 愛知工 業大学電気学科教授。工学博士

内田悦行 (正員) 1940 年 12 月 21 日生。1 1966 年 3 月早

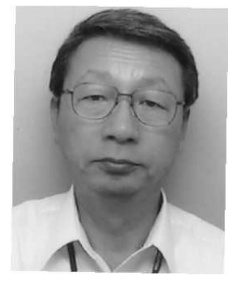
稲田大学大学院理工学研究科修士課程修了。名 古屋大学工学部助手, 愛知工業大学工学部電子 工学科助教授, 現在, 同大学電気学科教授。工 学博士。主としてオプトエレクトロニクスの技 法の開発とその応用システムならびに材料の 開発に関する研究と教育に従事。レーザー学会 応用物理学会, SPIE 会員。 


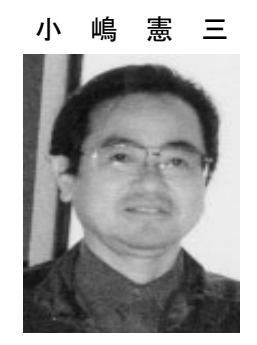

（正員） 1941 年 12 月 22 日生。 1970 年 3 月愛 知工業大学大学院工学研究科修士課程修了。同 年愛知工業大学電気工学科助手。光非線形薄膜 の電気伝導を測定し，光非線形性と電気伝導の 関係の解析に関する研究, 有機分子薄膜を各種 電子デバイスや光非線形素子一応用する研究 に従事。現在, 愛知工業大学電気学科教授。工 学博士。
水 谷 照吉 (正員) 1941 年 5 月 9 日生。1969 年 3 月名古 屋大学大学院工学研究科博士課程満了。同年 4 月より名古屋大学工学部電気学科助手, 講師, 助教授を経て 1987 年 7 月同教授, 2005 年 3 月 同定年退職。同年 4 月より名古屋大学名誉教授, 愛知工業大学客員教授, 現在に至る。工学博士。 1997 年電気学会業績賞受賞。主として誘電・絶 縁材料, 薄膜デバイス, 有機エレクトロニクス に関する研究に従事。IEEE, 応用物理学会, 高分子学会, 放電学会, CIGRE 会員。 